\title{
Colletotrichum Isolates Related to Anthracnose of Cashew Trees in Brazil: Morphological and Molecular Description Using LSU rDNA Sequences
}

\author{
Ana Maria Queijeiro Lopez ${ }^{1 *}$ and John Alexander Lucas ${ }^{2,3}$ \\ ${ }^{1}$ Instituto de Química e Biotecnologia; Universidade Federal de Alagoas; 57072-970; Maceió - AL - Brasil. \\ ${ }^{2}$ University of Bristol; Department of Agricultural Sciences; Bristol BS41 9AF - UK. ${ }^{3}$ IACR - Rothamsted; \\ Harpenden; Herts AL5 2JQ - UK
}

\begin{abstract}
Thirty six isolates of fungi obtained from anthracnose lesions of cashew and associated host plants in Brazil, were compared by their cultural, morphological and partial sequences of the 285 ribosomal DNA characters. They showed a high degree of cultural variability. The average mycelial growth rate on all tested media ranged from 10.2-13.3 mm/day between the isolates. Most of them produced perithecia (sterile and fertile) and some produced setae (sterile and fertile). All the isolates produced acervuli with predominantly cylindrical conidia (12.4-17.7 $\mu \mathrm{m} X$ 4.8-6.0 $\mu \mathrm{m}$ in width) with round ends, which became septate on germination, and produced unlobed or slightlylobed appressoria. Comparison of the D2 domain of the large subunit (LSU) rDNA sequences with those of other defined species of Colletotrichum and Glomerella grouped 35 of the isolates with known strains of C. gloeosporioides from different hosts (> 98.9\% homology). The one exception (LARS 921) was identical to G. cingulata (LARS 238) from Vigna unguiculata.
\end{abstract}

Key words: Anthracnose; inflorescence blight; Colletotrichum; rDNA; cashew; Anacardium occidentale

\section{INTRODUCTION}

The cashew (Anacardium occidentale L.) crop and associated agro-industrial business are of major socio-economic impact in three states of the Northeastern Brazil (Ceará, Rio Grande do Norte, and Piauí), providing annually incomes around 230 million dollars with exports of $90 \%$ of the production of the cashew nut and shell liquid (Sindicaju, 2007). This region accounts for the third highest cashew production (FAO, 2008). The major causes of direct or indirect losses are the inflorescence blight, fruit rot and leaf anthracnose, caused by the fungus morphologically described as the anamorphic stage of Glomerella cingulata
(Stoneman) Sp. and Schrenk, i.e., Colletotrichum gloeosporioides (Penz.) Penz. and Sacc. All the commercially available clones are susceptible to infection (Freire and Cardoso, 1995). Symptoms include sunken subcircular or angular lesions that produce erumpent, mucilaginous, orange spore masses in favorable environments. In general, such symptoms are similar in all cashew hosts from different localities, but the isolates of the pathogen may vary in its degree of aggressiveness as well as in its cultural and morphological characters.

Species concepts based on morphological criteria are generally broad for the genus Colletotrichum, and wide variations for cultural and morphological characters, pathogenicity and host range have been

*Author for correspondence: amq1@qui.ufal.br 
reported among isolates of $C$. gloeosporioides (Alahakoon and Brown, 1994; Gonçalves-Vidigal et al. 2008; Jeffries et al., 1990; Skipp et al., 1995; Menezes and Hanlin, 1996a, b; Sera et al. 2007). Sequence analyses of the intergenic transcribed spacers (ITS 1, ITS 2) and Domains (D1,D2) of large subunit (LSU) ribosomal DNA (rDNA) have been valuable for delineating isolates and species from this genus (Adaskaveg and Hartin, 1997; Forseille, 2007; Freeman et al., 2001; Johnston, 2000; Johnston and Jones, 1997; Moriwaki et al., 2002; Sherriff et al., 1994; Sreenivasaprasad et al., 1996; Vinnere et al., 2002).

In a study of $C$. gloeosporioides isolates from Stylosanthes spp. in Mexico, morphological and molecular criteria, including amplification and restriction of a specific fragment of the internal transcribed spacer 1 (ITS1) region of rDNA, were used to cluster the isolates into three groups partially related to their host species of origin (Munaut et al., 2001). Later, Abang et al. (2002) failed to distinguish $C$. coccodes from $C$. circinans based on restriction analysis of their ITS sequence. These authors hypothesized that these species were identical and could belong to the same taxon, in spite of apparent morphological differences. In further studies, Fagbola and Abang (2004) provided evidences of this differentiation of both species after amplifying their $18 \mathrm{~S}$ rDNA molecules (1.65 $\mathrm{Kb}$ long fragments), and submitting them to denaturing gradient gel electrophoresis (DGGE). Cano et al. (2004), however, demonstrated that sequencing of D1-D2 domains of the LSU rDNA gene also supported the results provided by the amplification of ITS1 in distinguishing between Colletotrichum spp. that were of human clinical interest. Further, Cannon et al. (2008) emphasized that the anamorphic species C. gloeosporioides had never been adequately typified in agreement to the modern nomenclatural practice, and there were three distinct rDNA ITS sequences of the epitype strain in GENEBANK, so it should be re-sequenced to confirm the true base-pair structure.

A better understanding on the population structure of $C$. gloeosporioides associated with anthracnose of cashew will increase the basis of recommendations for the management/control of disease, influencing in breeding programs. Since there are no good morphological markers for its subgroups, molecular markers, such as sequences of rDNA, are needed. This study aimed to determine the extent of variation in a collection of thirty six fungi isolates from anthracnose lesions in cashew and associated host plants in Brazil, combining the cultural, morphological and molecular criteria based on D2 nucleotide sequences of the LSU rDNA, to provide their identity.

\section{MATERIALS AND METHODS}

\section{Isolates and cultural characteristics}

Thirty six isolates of Colletotrichum from cashew and associated host plants were obtained from various locations in NE Brazil (Table 1). All the strains were subcultured on cornmeal agar (CMA) to ensure the purity (O'Connell et al., 1985). Spores were produced by subculturing the isolates in $100 \mathrm{ml}$ of Colletotrichum medium (CM) (Mathur et al., 1950) dispensed in flasks $(250 \mathrm{ml})$, for seven days, and the spore suspensions were obtained by adding $c a$. $20 \mathrm{ml}$ sterile distilled deionized water (SDW) to these cultures, and shaking. Then, single-spore cultures were produced from all the isolates prior to experimental use. The same procedure was carried out using reference strains from the Long Ashton Research Station-UK (LARS) collection, chosen as representatives of different morphological groups, with emphasis on those with straight conidia/spores that infected distinct hosts [C. capsici (LARS 141) and G. cingulata (LARS 238) from Vigna unguiculata; $C$. lindemuthianum (LARS 009) from Phaseolus vulgaris; $C$. acutatum (LARS 058) from Musa nana; C. malvarum (LARS 076) from Sida spinosa; $C$. trifolii (LARS 164) and $C$. destructivum (LARS 202) from Medicago sativa; C. orbiculare (LARS 414) from Cucumis sativus; and C. gloeosporioides from Stylosanthes scabra (LARS 167), S. sp (LARS 189), Mangifera indica (LARS 501) and Cucumis melo (LARS 781)].

Cultural morphology and mycelial growth rate of the studied isolates were determined by growing them on four different media [Oat meal agar OMA (Difco), PDA (Oxoid), CM (Mathur et al., 1950) and Czapek-Dox-V8 (CDV8)] dispensed in $9 \mathrm{~cm}$ dia. Petri dishes. CDV8 was prepared by adding 22.8 g Czapek Dox agar medium (Oxoid), 0.5g mycological peptone (Oxoid), $0.5 \mathrm{~g}$ yeast extract and $0.5 \mathrm{~g}$ casein hydrolysate to $100 \mathrm{ml} \mathrm{V8} \mathrm{juice}$ filtered through muslin cloth. A plug of mycelium (ca. $4 \mathrm{~mm}$ diameter), derived from single-spore 
cultures, was placed in the centre of the plates and the cultures were incubated $\left(25^{\circ} \mathrm{C}\right.$, black light). For growth-rate studies, the colony diameter of three replicates of each isolate on different media was recorded daily during 13 days. Cultures were left for a further 10 days and then examined for the presence of stroma, setae and perithecia.

Table 1 - Colletotrichum/Glomerella isolates from Brazil used in this study (include LARS 009, 058, 074, 076, 141, 164, 167, 202, 238, 414, 501, 781 from different origins).

\begin{tabular}{|c|c|c|c|}
\hline Isolates (LARS) & Origin & Infected Organ & Locality \\
\hline 905 & Rubus brasiliensis & Leaf & Maceió - Alagoas $^{1}$ \\
\hline 906 & Spondias purpurea $\mathrm{L}$. & Leaf & Maceió - Alagoas ${ }^{1}$ \\
\hline 907 & Carica papaya $\mathrm{L}$. & Leaf & Maceió - Alagoas ${ }^{1}$ \\
\hline 908 & Dioscorea $\mathrm{sp}$ & Leaf & Maceió - Alagoas ${ }^{1}$ \\
\hline 909 & Malpighia glabra L. & Leaf & Maceió - Alagoas ${ }^{1}$ \\
\hline 910 & Anacardium occidentale L. & Leaf & Maceió - Alagoas ${ }^{1}$ \\
\hline 911 & Anacardium occidentale L. & pseudo-fruit & Maceió - Alagoas ${ }^{1}$ \\
\hline 912 & Anacardium occidentale L. & Nut & Cruz das Almas - Bahia ${ }^{1}$ \\
\hline 913 & Anacardium occidentale L. & pseudo-fruit & Cruz das Almas - Bahia ${ }^{1}$ \\
\hline 914 & Anacardium occidentale L. & Leaf & Conceição do Almeida-Bahia ${ }^{1}$ \\
\hline 915 & Anacardium occidentale L. & Flower & Praia do Forte - Bahia ${ }^{1}$ \\
\hline 916 & Anacardium occidentale L. & Leaf & Indiaroba - Sergipe ${ }^{1}$ \\
\hline 917 & Anacardium occidentale L. & Leaf & Penedo - Alagoas ${ }^{1}$ \\
\hline 918 & Anacardium occidentale L. & Leaf & Maceió - Alagoas ${ }^{1}$ \\
\hline 919 & Anacardium occidentale L. & Leaf & Marechal Deodoro - Alagoas ${ }^{1}$ \\
\hline 920 & Anacardium occidentale L. & Leaf & Marechal Deodoro - Alagoas ${ }^{1}$ \\
\hline 921 & Anacardium occidentale L. & Leaf & Recife - Pernambuco ${ }^{2}$ \\
\hline 922 & Anacardium occidentale L. & pseudo-fruit & Belém - Pará ${ }^{3}$ \\
\hline 923 & Anacardium occidentale L. & Leaf & Fortaleza - Ceará ${ }^{3}$ \\
\hline 924 & Anacardium occidentale L. & Leaf & Pacajus - Ceará ${ }^{3}$ \\
\hline 925 & Anacardium occidentale L. & pseudo-fruit & Piracicaba - São Paulo ${ }^{3}$ \\
\hline 926 & Anacardium occidentale L. & Leaf & Cruz das Almas - Bahia ${ }^{3}$ \\
\hline 927 & Anacardium occidentale L. & pseudo-fruit & Fortaleza - Ceará ${ }^{3}$ \\
\hline 928 & Anacardium occidentale L. & pseudo-fruit & Brasília (DF) - Goiás ${ }^{3}$ \\
\hline 929 & Anacardium occidentale L. & pseudo-fruit & Pacajus - Ceará ${ }^{4}$ \\
\hline 930 & Anacardium occidentale L. & Leaf & Goiana - Pernambuco ${ }^{4}$ \\
\hline 931 & Anacardium occidentale L. & Leaf & Recife - Pernambuco ${ }^{4}$ \\
\hline 932 & Anacardium occidentale L. & Leaf & Fortaleza - Ceará ${ }^{4}$ \\
\hline 933 & Anacardium occidentale L. & Leaf & Areia - Pernambuco ${ }^{4}$ \\
\hline 934 & Anacardium occidentale L. & Leaf & Natal - Rio Grande do Norte ${ }^{4}$ \\
\hline 935 & Anacardium occidentale L. & Leaf & Recife - Pernambuco ${ }^{4}$ \\
\hline 936 & Anacardium occidentale L. & Leaf & Maceió - Alagoas ${ }^{4}$ \\
\hline 937 & Anacardium occidentale L. & Leaf & Olinda - Pernambuco ${ }^{4}$ \\
\hline 938 & Anacardium occidentale L. & Leaf & João Pessoa - Paraíba ${ }^{4}$ \\
\hline 939 & Anacardium occidentale L. & Leaf & Manaus - Amazonas ${ }^{5}$ \\
\hline 940 & Anacardium occidentale L. & Leaf & Pacajus - Ceará ${ }^{5}$ \\
\hline
\end{tabular}

Isolates were provided in 1996 by : ${ }^{1}$ Prof. Dr. Eurico Lemos, "Centro de Ciências Agrárias - UFAL", Maceió/AL; ${ }^{2}$ Dr. M.B. Figueiredo, "Seção de Micologia - Instituto Biológico", SP ${ }^{3}$ Dr. E.E. Bach, "Seção de Bioquímica Vegetal - Instituto Biológico", SP; ${ }^{4}$ Prof. Dr. M. Menezes, "Departamento de Fitossanidade - UFRPe", Recife/Pe; ${ }^{5}$ Dr. F.P. Freire, "Centro Nacional de Pesquisa da Agroindústria Tropical - EMBRAPA”, Fortaleza/Ce.

\section{Conidial morphology, germination and formation of appressoria}

Conidial suspensions $\left(5 \times 10^{5}\right.$ conidia $\left./ \mathrm{ml}\right)$ of each isolate were prepared from CM flask cultures and the shape and dimensions of 30 spores were determined under a Zeiss Axiophot light microscope fitted with a graticule eyepiece. Drops $(10 \mu \mathrm{l})$ of the conidial suspensions were placed in the wells of cavity slides that had been acidwashed (ICN-Flow, High Wycombe, Bucks, UK) and incubated in a humid chamber at $25^{\circ} \mathrm{C}$ for $16-$ $24 \mathrm{~h}$ in the dark. Germinating conidia were 
examined by light microscopy (Zeiss Axiophot, Nomarski DIC) for septum and appressorium development, and the shape, average length and width of 30 appressoria from each isolate were measured.

\section{DNA preparation}

Conidial suspensions from CM flask cultures were used to inoculate $100 \mathrm{ml}$ of Czapek Dox-V8 liquid medium in $250 \mathrm{ml}$ flasks (Sherriff et al., 1994). The flasks were incubated at $25^{\circ} \mathrm{C}$ on an orbital shaker $(126 \mathrm{rpm})$ for $48 \mathrm{~h}$. To test for yeast or bacterial contamination, LB medium (Gibco BRL) was inoculated with a small aliquot of the culture fluid, just before harvest of the mycelium, and incubated for $48 \mathrm{~h}\left(25^{\circ} \mathrm{C}\right.$ dark). The mycelium was harvested by filtration (Whatman $\mathrm{n}^{\mathrm{o}} 1$ filter paper), using a Buchner funnel and vacuum pump, and washed with $200 \mathrm{ml}$ of SDW. The liquid was removed by vacuum and the harvested mycelium was ground to powder in liquid nitrogen, with a pestle and a mortar. This was transferred to plastic tubes, freeze-dried for $24 \mathrm{~h}$ and stored at $-20^{\circ} \mathrm{C}$.

DNA was extracted from the powdered mycelium using a method adapted from Graham et al. (1994). A 2-ml screw-top Eppendorf tube was one-third filled with ground mycelium and $1.5 \mathrm{ml}$ of hot $\left(65^{\circ} \mathrm{C}\right)$ extraction buffer [TE: $100 \mathrm{mM}$ Tris$\mathrm{HCl}, 20 \mathrm{mM}$ EDTA, $1.4 \mathrm{M} \mathrm{NaCl}$ and $2 \% \mathrm{CTAB}$ $(\mathrm{w} / \mathrm{v})$ ] was added. After mixing thoroughly, the well-soaked mycelium was incubated at $65^{\circ} \mathrm{C}$ for $30 \mathrm{~min}$ and then centrifuged at $16,000 \mathrm{~g}$ for 10 min. The supernatant was transferred to a new Eppendorf tube and to remove the proteins, one volume of $\mathrm{CHCl}_{3}$ : isoamyl-alcohol $(24: 1 \mathrm{v} / \mathrm{v})$ was added and mixed by gentle inversion for 1-2 min. The suspension was then centrifuged $(16,000 \mathrm{~g}, 3$ min) and the upper aqueous phase collected in a 2 $\mathrm{ml}$ "Dolphin" microcentrifuge tube (Multi Dolphin Safe Seal Tubes, Sorenson BioScience Inc.). This was added with a 0.1 volume of $4 \mathrm{M}$ sodium acetate and 2.5 volumes of ice-cold absolute $\mathrm{EtOH}$. The contents of the tube were gently mixed and the DNA was precipitated at $-80^{\circ} \mathrm{C}$ for $10 \mathrm{~min}$. After centrifugation $(16,000 \mathrm{~g})$ for $1 \mathrm{~min}$, the supernatant was discarded and the pellet was washed twice with $70 \% \mathrm{EtOH}$, mixing gently by inversion. The resulting DNA pellet was dried at $65^{\circ} \mathrm{C}$ on a heating block for $3-5 \mathrm{~min}$, and dissolved in $200 \mu \mathrm{l} \mathrm{TE}$ buffer plus RNAase $(50 \mu \mathrm{g} / \mathrm{ml})$ at $37^{\circ} \mathrm{C}$ for $1 \mathrm{~h}$. To remove the RNAase, all the previous steps from the addition of $\mathrm{CHCl}_{3}$ : isoamyl-alcohol $(24: 1 \mathrm{v} / \mathrm{v})$ to the dried pellet DNA were repeated. The DNA was dissolved in $100 \mu \mathrm{l}$ of TE buffer $\left(37^{\circ} \mathrm{C}, 1 \mathrm{~h}\right)$ and stored at $4^{\circ} \mathrm{C}$ before amplification by PCR (Sambrook et al., 1989).

\section{Amplification of rDNA}

The concentration of DNA extracted from the mycelial samples was determined at $260 \mathrm{~nm}$ in a HP D-8452 spectrophotometer. Samples were diluted to $0.1 \mu \mathrm{g} / \mu \mathrm{l}$ with $1 / 10 \mathrm{TE}$ buffer, and used in the polymerase chain reactions (PCR). Amplification of rDNA repeat sequences was carried out using the Perkin Elmer GeneAmp PCR Kit [Buffer, deoxynucleosides Triphosphate (dNTPs) and AmpliTaq DNA Polymerase] and Thin-walled PCR Tubes (both from Applied Biosystems), in a thermocycler (Perkin Elmer Cetus 480). The 10X PCR buffer contained 100 $\mathrm{mM}$ Tris- $\mathrm{HCl} \mathrm{pH} 8.3,500 \mathrm{mM} \mathrm{KCl}, 15 \mathrm{mM}$ $\mathrm{MgCl}_{2}, 0.01 \%$ (w/v) and gelatin, and the dNTPs were dATP, dCTP, dGTP and dTTP.

Domain 2 within the 28S gene was amplified using the primers Pn 2 (5'-GTT CAC CAT CTT TCG GGT CC-3') and Pn 9 (5'-CTT AAG CAT ATC AAT AAG CGG AGG-3') (Guadet et al., 1989; Sherriff et al., 1994). The reaction mixture per PCR tube consisted of $10 \mu \mathrm{l}$ of water-diluted DNA sample $(0.1 \mu \mathrm{g} / \mu \mathrm{l}), 2 \mu \mathrm{l}$ of each primer $(50$ $\mathrm{pmol} / \mu \mathrm{l}, 2 \mu \mathrm{l}=1 \mu \mathrm{M}$ of each), $2 \mu \mathrm{l}$ of each dNTP (0.2 mM of each dATP, dCTP, dGTP and dTTP), $10 \mu \mathrm{l}$ of PCR buffer, $0.5 \mu \mathrm{l}$ of AmpliTaq DNA polymerase (2.5 Units) and $67.5 \mu \mathrm{l}$ of SDW. The DNA samples plus the reaction mixture were overlaid with $50 \mu 1$ PCR mineral oil (Sigma). PCR was carried out using the following thermocycler program: initial denaturation $96^{\circ} \mathrm{C}, 120 \mathrm{~s}$; then, 30 cycles of $15 \mathrm{~s}$ at $96^{\circ} \mathrm{C}$ (denaturing), $30 \mathrm{~s}$ at $60{ }^{\circ} \mathrm{C}$ (annealing), $60 \mathrm{~s}$ at $72^{\circ} \mathrm{C}$ (elongation), followed by a final $90 \mathrm{~s}$ extension step at $72^{\circ} \mathrm{C}$ and their storage at $4^{\circ} \mathrm{C}$. Samples of PCR product $(8 \mu \mathrm{l}$ plus $8 \mu \mathrm{l}$ of $2 \mathrm{X}$ Orange $\mathrm{G}$ ) were electrophoresed on $0.8 \%$ agarose gel in TBE/Eb, against $0.1 \mu \mathrm{g}$ of DNA size marker (100 bp, $1 \mu \mathrm{g} / \mu \mathrm{l})$.

\section{DNA Sequencing}

Sequencing reactions were carried out using the Sequenase PCR Product Sequencing Kit (USB Amersham International plc, USA) and the protocol provided by the supplier. Primer Pn 4 (5'- CCT TGG TCC GTG TTT CAA GAC GGG3') was diluted in sterile deionised water. Sequencing gels were prepared from SeqGel (NBL 
Gene Sciences Ltd.), containing 6\% acrylamide: bisacrylamide (19:1) and $7 \mathrm{M}$ urea. When ready to pour, ammonium persulfate and also N,N,N',N'tetra-methyl ethylene diamine (TEMED) was added to the gels. They were run on a vertical electrophoresis system (Base Runner Nucleic Acid Sequencer, International Biotech. Inc., USA). The developed gel was read manually, and each sequence was aligned using GCG PileUp. Data obtained from the sequencing of the D2 region of all isolates were compared with those of the D2 regions of some Colletotrichum species previously studied (Bailey et al., 1996; Moses et al., 1996; Sherriff et al., 1994), using the neighbour-joining method of Kumar et al. (1993), and a dendrogram depicting similarities was constructed using the MEGA (Molecular Evolutionary Genetic Analysis) software (version 1.01).

\section{RESULTS AND DISCUSSION}

\section{Cultural morphology}

The isolates examined varied in growth rate (Table 2) and cultural morphology on the four media tested. On PDA, aerial mycelium was velvety to densely floccose, with a gradual tendency from white-greyish to dark green-moss pigmentation.

On OMA, the colonies were less variable, with predominance of white-greyish floccose mycelium covering an abundant mucilaginous mass of orange acervuli and spores. CZD-V8 also induced abundant formation of acervuli in most isolates, although resulting in a slighter floccose and thinner greyish to green-moss mycelium.

Table 2 - In vitro growth of Colletotrichum isolates.

\begin{tabular}{|c|c|c|c|c|c|c|}
\hline \multirow{2}{*}{$\begin{array}{c}\text { Isolates } \\
\text { LARS }\end{array}$} & \multicolumn{5}{|c|}{ Mean Growth Rate $(\mathrm{mm} / \mathrm{day})^{1}$} & \multirow{2}{*}{ LSD $_{1 \%}$} \\
\hline & CM & OMA & CZD-V8 & PDA & Mean & \\
\hline 905 & $11.77+1.58$ & $12.00+1.00$ & $9.57+1.25$ & $12.33+0.58$ & $11.42+1.15$ & 3.19 \\
\hline 906 & $12.33 \pm 0.85$ & $11.77 \pm 0.68$ & $12.43 \pm 0.51$ & $10.33+1.82$ & $11.72+0.97$ & 3.00 \\
\hline 907 & $10.57 \pm 2.14$ & $9.23 \pm 0.68$ & $12.67 \pm 1.52$ & $11.10 \pm 0.95$ & $10.89 \pm 1.42$ & 3.94 \\
\hline 908 & $12.33+3.76$ & $9.00+1.00$ & $11.00+2.00$ & $13.10+1.85$ & $11.36+1.15$ & 6.52 \\
\hline 909 & $12.57+4.05$ & $11.90+1.65$ & $12.33+1.75$ & $12.67+2.08$ & $12.37+0.34$ & 7.07 \\
\hline 910 & $13.43 \pm 2.98$ & $12.33 \pm 0.58$ & $13.67 \pm 1.19$ & $12.00 \pm 1.73$ & $12.86 \pm 1.15$ & 5.06 \\
\hline 911 & $13.33+0.65$ & $12.67+0.58$ & $12.43+0.51$ & $13.33+0.58$ & $12.94+0.82$ & 1.60 \\
\hline 912 & $12.33+1.15$ & $10.00+1.00$ & $12.00+1.80$ & $12.67+3.79$ & $11.75+1.20$ & 6.12 \\
\hline 913 & $12.00 \pm 3.46$ & $9.67 \pm 0.58$ & $11.33 \pm 0.58$ & $12.33 \pm 1.15$ & $11.33 \pm 1.18$ & 5.12 \\
\hline 914 & $13.67+3.21$ & $10.43 \pm 0.75$ & $11.00 \pm 0$ & $13.33+1.65$ & $12.10 \pm 1.63$ & 5.06 \\
\hline 915 & $10.67 \pm 0.85$ & $9.10 \pm 1.15$ & $10.00 \pm 1.00$ & $10.90 \pm 1.56$ & $10.17 \pm 0.81$ & 3.21 \\
\hline 916 & $12.67+1.23$ & $12.00+1.00$ & $7.00+1.78$ & $13.23+0.40$ & $11.23+0.29$ & $3.32 *$ \\
\hline 917 & $13.00+0$ & $9.67+2.08$ & $12.67+1.15$ & $12.90+0.17$ & $12.06+1.60$ & 3.27 \\
\hline 918 & $12.77 \pm 2.25$ & $8.67+1.53$ & $13.67+0.58$ & $12.00+1.18$ & $11.78+1.15$ & $4.15^{*}$ \\
\hline 919 & $10.67+4.04$ & $12.67+0.58$ & $13.33+0.58$ & $13.90+1.01$ & $12.64+1.41$ & 5.82 \\
\hline 920 & $12.67+4.04$ & $10.33+0.58$ & $13.33+0.58$ & $12.23+2.14$ & $12.14+1.29$ & 6.37 \\
\hline 921 & $12.00+2.00$ & $9.01+1.59$ & $11.33+1.53$ & $13.01+0.85$ & $11.34+1.70$ & 4.25 \\
\hline 922 & $12.57+2.23$ & $10.77 \pm 3.61$ & $15.67+3.79$ & $10.33+0.58$ & $12.34+2.43$ & 7.84 \\
\hline 923 & $13.00+2.00$ & $11.67+3.35$ & $13.00+0.89$ & $14.33+2.57$ & $13.00+1.09$ & 6.53 \\
\hline 924 & $12.33+2.17$ & $10.43+3.16$ & $12.67+1.53$ & $13.33+1.42$ & $12.19+1.24$ & 5.99 \\
\hline 925 & $11.87 \pm 1.69$ & $10.00 \pm 1.73$ & $13.67 \pm 3.81$ & $11.33 \pm 2.90$ & $11.72 \pm 1.37$ & 7.36 \\
\hline 926 & $11.43+2.14$ & $14.00 \pm 2.65$ & $13.33+1.46$ & $13.00 \pm 1.00$ & $12.94+1.09$ & 5.27 \\
\hline 927 & $12.33 \pm 2.89$ & $13.67 \pm 2.31$ & $13.57 \pm 3.19$ & $12.00 \pm 2.65$ & $12.89 \pm 0.81$ & 7.62 \\
\hline 928 & $10.33+0.85$ & $10.00+1.00$ & $11.33+4.04$ & $10.43+0.74$ & $10.52+0.57$ & 5.92 \\
\hline 929 & $12.00+4.63$ & $12.33+4.93$ & $9.00+3.00$ & $12.67+3.06$ & $11.50+1.69$ & 10.98 \\
\hline 930 & $10.43 \pm 0.85$ & $14.00 \pm 6.33$ & $13.67 \pm 5.51$ & $13.67 \pm 6.61$ & $12.94+1.69$ & 14.71 \\
\hline 931 & $11.67+4.03$ & $8.67+1.05$ & $13.67+2.76$ & $12.00+0.30$ & $11.50+2.08$ & 6.87 \\
\hline 932 & $13.23+2.04$ & $11.57+3.35$ & $13.23+1.52$ & $12.00+1.00$ & $12.51+0.85$ & 5.93 \\
\hline 933 & $12.00 \pm 2.65$ & $12.00 \pm 1.18$ & $13.87 \pm 5.34$ & $15.35 \pm 3.32$ & $13.31 \pm 1.62$ & 9.50 \\
\hline 934 & $8.57 \pm 1.25$ & $10.00 \pm 1.00$ & $10.33 \pm 0.58$ & $11.77 \pm 1.20$ & $10.17 \pm 1.31$ & $2.85^{*}$ \\
\hline 935 & $13.43+3.61$ & $10.33+2.65$ & $13.00+1.00$ & $14.00+5.27$ & $12.69+1.63$ & 9.60 \\
\hline 936 & $8.87 \pm 1.40$ & $10.33 \pm 1.65$ & $13.67 \pm 3.79$ & $13.00 \pm 3.00$ & $11.47 \pm 2.25$ & 7.26 \\
\hline 937 & $10.77+2.25$ & $10.00+0$ & $11.67+1.80$ & $10.67+1.53$ & $10.78+0.69$ & 4.48 \\
\hline 938 & $10.00 \pm 2.34$ & $11.00 \pm 1.00$ & $10.33 \pm 0.58$ & $10.33 \pm 0.55$ & $10.42 \pm 0.42$ & 3.67 \\
\hline 939 & $12.67+2.35$ & $14.13+1.50$ & $12.33+1.53$ & $12.43+1.50$ & $12.89+0.84$ & 4.83 \\
\hline 940 & $12.67+0.58$ & $11.00+3.32$ & $13.80+1.15$ & $12.67+1.35$ & $12.54+1.15$ & 5.22 \\
\hline Mean & $11.92 \pm 1.25$ & $11.01 \pm 1.56$ & $12.27 \pm 1.69$ & $12.44 \pm 1.21$ & 11.91 & $0.88 *$ \\
\hline $\operatorname{LSD}_{1 . \%}$ & 5.42 & $4.73 *$ & $4.91 *$ & $4.82 *$ & $2.48^{*}$ & - \\
\hline
\end{tabular}

${ }^{1}$ Growth rates of the colonies between the $3^{\text {rd }}$ and $6^{\text {th }}$ day after inoculation on the media. Highest and lowest averages on the same tested medium are depicted in bold. LSD $1 \%$ followed by asterisk $(*)$ indicates that significant differences were detected between 2 treatments of the same column or row. 
OMA, CM and PDA induced considerable production of conidia in the aerial mycelium, and on PDA this was the predominant type of sporulation. CM induced more acervuli formation than PDA and less aerial sporulation than PDA and OMA. The reverse of the cultures was mostly greyish-white to dark green-moss. Generally, mycelial growth at $25^{\circ} \mathrm{C}$ was more profuse on PDA, moderate on CZD-V8 and CM, and least on OMA (Table 2). These findings were in agreement with studies of Lenné (1978), who reported that mycelial growth of numerous Colletotrichum species was always greater on PDA than OMA. When growth rates were evaluated on the same medium, there was no highly significant difference on $\mathrm{CM}$, but some isolates showed considerable variation on the other media, for example from 7 $15.7 \mathrm{~mm}$ per day on CZD-V8. For some isolates a highly significant variation occurred between the daily mycelial growth rate on different media. However, for most of the isolates, the growth rates were not significantly different (LSD 5\% for comparing two media), even between the media, this criterion did not separate them into groups.

Several authors have reported average daily growth rates for the isolates of $C$. gloeosporioides from various host plants on PDA and other media. Overall, maximum growth rates of between 6.2 and $16.6 \mathrm{~mm}$ per day have been measured at optimum temperatures between 25 and $30 \mathrm{oC}$ (Adaskaveg and Hartin, 1997; Kuramae-Izioka et al., 1997; Lenné, 1978). Muniz et al. (1997) recorded growth of $C$. gloeosporioides isolates from cashew on malt extract agar (MEA) and showed that maximum rates $(7.7-14.8 \mathrm{~mm} /$ day) occurred from 25 to $30^{\circ} \mathrm{C}$. The isolates of $\mathrm{C}$. acutatum, however, exhibited much slower growth, with a maximum at $25^{\circ} \mathrm{C}$ (Adaskaveg and Hartin, 1997; Agostini et al., 1992; Brown et al., 1996; Kuramae-Izioka et al., 1997; Smith and Black, 1990). Since this distinction was provided by the molecular approaches like RAPDs and sequencing of ITS, Adaskaveg and Hartin (1997) suggested that temperature relationships could be combined with the mycelial growth rates to distinguish C. acutatum from C. gloeosporioides.

\section{Morphology of spores, germination and appressorium formation}

In the present study, the spores (Table 3) of most of the isolates on PDA were generally straight with rounded apices, typical of $C$. gloeosporioides conidia, but some single-spore cultures also produced straight spores with one or two obtuse apices. Conidial morphology has also been used in taxonomic investigations of Colletotrichum spp. (Adaskaveg and Hartin, 1997; Lane et al., 1998; Menezes and Hanlin, 1996a, b; Moriwaki et al., 2002). According to the studies of Munaut et al. (2001), although the majority of isolates of $C$. gloeosporioides from Stylosanthes formed straight spores, many produced falcate ones.

Conidial length was considerably more variable than width. The ratio of the shortest $(907=12.42$ $\mu \mathrm{m})$ to the longest $(917=17.67 \mu \mathrm{m})$ isolateconidia was $1: 1.42$, and of the narrowest $(935=$ $4.79 \mu \mathrm{m})$ to the broadest $(928=5.99 \mu \mathrm{m})$ isolateconidia was 1:1.25. These ratios were in agreement to the observations of Menezes and Hanlin (1996b), in which the isolates of $C$. gloeosporioides from avocado, cashew, citrus, guava, soursop and mango, the corresponding ratios were $1: 1.41$ and 1:1.28, respectively. The length/width $(\mathrm{L} / \mathrm{W})$ ratio of the conidia of the isolates ranged from 2.49 to 3.41, in agreement with the findings of Andrade et al. (2007) and Menezes and Hanlin (1996b).

The germination of conidia in vitro on glass slides, with the formation of a single septum (Table 3), followed by the production of hyaline appressoria, was observed within $6 \mathrm{~h}$ for all the isolates. By 24 $\mathrm{h}$, the appressoria had melanized, appearing light to dark brown, thick walled with a hyaline germpore. Appressoria varied in morphology from globose, with a diameter of 6.3-7.5 $\mu \mathrm{m}$, to subglobose, with lengths of 5-10 $\mu \mathrm{m}$ and widths of 5-9 $\mu \mathrm{m}$ (Table 3), similar to results for $C$. gloeosporioides reported by Baxter et al.(1983). Cox and Irwin (1988) suggested the existence of three groups within the isolates which were originally classified as C. gloeosporioides. The first comprised the isolates with mean conidial widths between 3 and $4.2 \mu \mathrm{m}$, and with either unlobed or slightly-lobed appressoria. The second had the isolates with mean conidial widths between 4.5 and $5.5 \mu \mathrm{m}$, and with unlobed or slightly-lobed appressoria. The third group comprised the isolates with conidial widths between 4.5 and $5.5 \mu \mathrm{m}$, but with obviously lobed appressoria, compatible with the definitions of $C$. crassipes. All the isolates of this work had similarities with the second group of $C$. gloeosporioides defined by Cox and Irwin (1988). 
Table 3 - Morphology and dimensions of conidia and appressoria of Colletotrichum isolates in vitro (all of them produce septum only after the germination).

\begin{tabular}{|c|c|c|c|c|c|c|}
\hline $\begin{array}{l}\text { Isolate } \\
\text { LARS }\end{array}$ & $\begin{array}{l}\text { Conidial } \\
\text { Shape }^{1}\end{array}$ & $\begin{array}{c}\text { Mean } \\
\text { Conidial Length } \\
\end{array}$ & $\begin{array}{c}\text { Mean } \\
\text { Conidial Width }\end{array}$ & $\begin{array}{c}\text { Appressorial } \\
\text { Shape }^{2} \\
\end{array}$ & $\begin{array}{c}\text { Mean } \\
\text { Appressorial length }\end{array}$ & $\begin{array}{c}\text { Mean } \\
\text { Appressorial Width }\end{array}$ \\
\hline 905 & cylindrical* & $14.62 \pm 2.11$ & $4.92 \pm 0.32$ & globose ${ }^{\mathbb{4}}$ & $6.28 \pm 0.32$ & $6.26 \pm 0.12$ \\
\hline 906 & cylindrical & $14.95 \pm 1.08$ & $5.00 \pm 0$ & subglobose $\mathrm{e}^{\mathrm{q}}$ & $6.29 \pm 0.29$ & $7.39 \pm 0.24$ \\
\hline 907 & cylindrical* & $12.42 \pm 1.27$ & $4.98 \pm 0.09$ & globose $^{\text {qI }}$ & $7.42 \pm 0.24$ & $6.43 \pm 0.29$ \\
\hline 908 & cylindrical & $15.00 \pm 0.66$ & $5.00 \pm 0$ & $\begin{array}{c}\text { globose/ } \\
\text { subglobose }\end{array}$ & $7.51 \pm 0.30$ & $7.50 \pm 0.15$ \\
\hline 909 & cylindrical* & $17.00 \pm 2.40$ & $5.00 \pm 0$ & subglobose $\mathrm{e}^{\S}$ & $5.64 \pm 0.32$ & $7.50 \pm 0$ \\
\hline 910 & cylindrical* & $12.67 \pm 0.43$ & $5.00 \pm 0$ & subglobose $\mathrm{e}^{\mathrm{I}}$ & $5.55 \pm 0.33$ & $7.50 \pm 0$ \\
\hline 911 & cylindrical* & $16.55 \pm 1.23$ & $4.95 \pm 0.23$ & subglobose $\mathrm{e}^{\mathrm{q}}$ & $8.05 \pm 0.27$ & $7.35 \pm 0.65$ \\
\hline 912 & cylindrical* & $17.20 \pm 1.99$ & $5.00 \pm 0$ & subglobose $\mathrm{e}^{\mathrm{I}}$ & $5.17 \pm 0.21$ & $7.50 \pm 0$ \\
\hline 913 & cylindrical** & $17.73 \pm 1.94$ & $5.00 \pm 0$ & globose $^{\text {qI }}$ & $7.49 \pm 0.17$ & $7.50 \pm 0$ \\
\hline 914 & cylindrical & $15.43 \pm 2.23$ & $5.00 \pm 0$ & subglobose $\mathrm{e}^{\mathrm{q}}$ & $7.08 \pm 0.55$ & $8.73 \pm 0.13$ \\
\hline 915 & cylindrical & $16.20 \pm 3.48$ & $5.08 \pm 0.28$ & subglobose $\mathrm{e}^{\mathrm{q}}$ & $5.02 \pm 0.18$ & $7.28 \pm 0.66$ \\
\hline 916 & cylindrical* & $16.13 \pm 1.63$ & $5.0 \overline{0} \pm 0$ & subglobose $\mathrm{e}^{\mathrm{T}}$ & $9.95 \pm 0.24$ & $7.5 \overline{0} \pm 0$ \\
\hline 917 & cylindrical* & $17.67 \pm 4.17$ & $5.17 \pm 0.56$ & subglobose ${ }^{\S}$ & $9.98 \pm 0.17$ & $7.50 \pm 0$ \\
\hline 918 & cylindrical* & $16.01 \pm 0.22$ & $5.00 \pm 0$ & subglobose $\mathrm{e}^{\S}$ & $8.28 \pm 0.48$ & $6.98 \pm 0.96$ \\
\hline 919 & cylindrical & $15.07 \pm 1.50$ & $5.00 \pm 0$ & subglobose $\mathrm{e}^{\S}$ & $6.70 \pm 0.85$ & $6.10 \pm 0.60$ \\
\hline 920 & cylindrical $^{\#}$ & $14.92 \pm 1.03$ & $5.00 \pm 0$ & subglobose $\mathrm{e}^{\S}$ & $5.04 \pm 0.20$ & $7.50 \pm 0$ \\
\hline 921 & cylindrical & $15.06 \pm 0.59$ & $5.07 \pm 0.17$ & subglobose $\mathrm{e}^{\S}$ & $9.42 \pm 1.08$ & $6.58 \pm 1.23$ \\
\hline 922 & cylindrical* & $14.88 \pm 0.89$ & $5.00 \pm 0$ & subglobose $\mathrm{e}^{\S}$ & $8.21 \pm 1.34$ & $6.92 \pm 0.91$ \\
\hline 923 & cylindrical* & $16.00 \pm 4.13$ & $5.00 \pm 0$ & subglobose $\mathrm{e}^{\S}$ & $8.54 \pm 1.64$ & $6.58 \pm 0.92$ \\
\hline 924 & cylindrical & $17.58 \pm 2.43$ & $5.00 \pm 0$ & subglobose $\mathrm{s}^{\S}$ & $7.88 \pm 1.23$ & $7.38 \pm 0.68$ \\
\hline 925 & cylindrical & $15.58 \pm 2.52$ & $5.00 \pm 0$ & subglobose ${ }^{\S}$ & $8.42 \pm 1.31$ & $7.17 \pm 0.56$ \\
\hline 926 & cylindrical & $15.46 \pm 1.29$ & $5.08 \pm 0.19$ & globose $^{\text {ql }}$ & $8.54 \pm 1.19$ & $7.50 \pm 0$ \\
\hline 927 & cylindrical* & $17.00 \pm 4.80$ & $5.0 \overline{0} \pm 0$ & subglobose ${ }^{\S}$ & $8.88 \pm 1.06$ & $7.33 \pm \overline{0} .43$ \\
\hline 928 & cylindrical & $16.17 \pm 3.41$ & $5.99 \pm 1.10$ & subglobose $\mathrm{e}^{\S}$ & $9.39 \pm 0.47$ & $7.33 \pm 0.54$ \\
\hline 929 & cylindrical & $15.08 \pm 1.43$ & $5.0 \overline{0} \pm 0$ & subglobose $\mathrm{f}^{\S}$ & $7.42 \pm 1.47$ & $5.83 \pm 1.20$ \\
\hline 930 & cylindrical & $14.88+1.84$ & $5.00 \pm 0$ & subglobose $\mathrm{e}^{\S}$ & $9.25 \pm 1.02$ & $7.5 \overline{0} \pm 0$ \\
\hline 931 & cylindrical* & $16.17 \pm 4.22$ & $5.00 \pm 0$ & subglobose $e^{\S}$ & $9.71 \pm 1.26$ & $7.46 \pm 0.23$ \\
\hline 932 & cylindrical*\# & $16.08 \pm 1.49$ & $5.12 \pm 0.22$ & globose $^{\text {II }}$ & $8.21 \pm 1.07$ & $7.38 \pm 0.38$ \\
\hline 933 & cylindrical & $16.13 \pm 0.95$ & $4.95 \pm 0.25$ & subglobose $\mathrm{e}^{\mathrm{q}}$ & $8.88 \pm 1.15$ & $7.50 \pm 0.33$ \\
\hline 934 & cylindrical & $16.13 \pm 2.06$ & $5.0 \overline{0} \pm 0$ & subglobose $\mathrm{II}^{\text {I }}$ & $8.75 \pm 1.23$ & $7.38 \pm 0.50$ \\
\hline 935 & cylindrical & $13.40 \pm 1.34$ & $4.79 \pm 0.47$ & subglobose $\mathrm{e}^{\mathrm{q}}$ & $7.75 \pm 0.76$ & $5.46 \pm 0.70$ \\
\hline 936 & cylindrical & $13.75 \pm 1.27$ & $5.0 \overline{0} \pm 0$ & subglobose $\mathrm{s}^{\S}$ & $9.21 \pm 1.06$ & $6.92 \pm 0.63$ \\
\hline 937 & cylindrical & $15.04 \pm 0.84$ & $5.00 \pm 0$ & subglobose $\mathrm{e}^{\S}$ & $8.75 \pm 1.04$ & $7.33 \pm 0.43$ \\
\hline 938 & cylindrical & $15.75 \pm 1.63$ & $5.00 \pm 0$ & subglobose $\mathrm{e}^{\mathrm{I}}$ & $9.08+1.23$ & $5.38 \pm 0.81$ \\
\hline 939 & cylindrical* & $15.54 \pm 1.70$ & $5.33 \pm 0.56$ & subglobose $\mathrm{e}^{\mathrm{q}}$ & $6.63 \pm 1.51$ & $5.54 \pm 0.37$ \\
\hline 940 & cylindrical* & $15.42 \pm 2.28$ & $5.00 \pm 0$ & subglobose ${ }^{\S}$ & $8.04 \pm 0.85$ & $6.21 \pm 0.70$ \\
\hline LSD & - & 1.46 & 0.01 & - & 0.60 & 0.43 \\
\hline
\end{tabular}

${ }^{1}$ Predominant shape of conidia in vitro $(\geq 70 \%)$ : cylindrical with rounded ends. Some isolates produced also: $*=$ ovoid (one obtuse apex); \# = ellipsoid (two obtuse apices) conidia. ${ }^{2}$ Predominant shape of appressoria in vitro $(>50 \%)$ : ${ }^{\mathbb{I}}=$ smooth ; $\S=$ irregular.

\section{Morphology of perithecia and setae}

Most isolates (64\%) produced embedded or partially embedded perithecia, singly or in small stromata scattered over the colony surface. The majority of these embedded perithecia, when crushed for microscopic examination, were found to be sterile or producing few visible ascospores. Some isolates also produced large aggregated perithecia in embedded or prominent stromata or in tufted mycelium that were always fertile. The sterile perithecia were morphologically identical to the fertile form, with a diameter between 275 and $304 \mu \mathrm{m}$, while the length of the canal-lined ostiole varied from 277 to $292 \mu \mathrm{m}$. Irwin and Cameron (1978) reported that Type A of $C$. gloeosporioides from Stylosanthes produced sterile perithecia in pure cultures. Gunnel and Gubler (1992) reclassified some isolates as C. gloeosporioides, based on the presence of fertile as well as sterile perithecia, when they had been previously 
identified as $C$. fragariae because of their production of sterile perithecia. The asci of the fertile perithecia of the different isolates were curved fusiform (60-69 $\mu \mathrm{m}$ in length) and contained eight cylindrical rounded to fusiform hyaline and aseptate ascospores $(17-22 \mu \mathrm{m}$ in length). The observation of the ascogenous phase in these monoconidial isolates confirmed that they were homothallic (self-fertile) in agreement with the findings of Lenné (1978) for $C$. gloeosporioides.

\section{Molecular characterization}

Comparing the aligned nucleotide sequences of the D2 region (180 nucleotides) of the studied isolates, along with data of other previously-identified
Colletotrichum species from LARS collection (Bailey et al., 1996; Moses et al., 1996; Sherriff et al., 1994), the maximum number of differences among the aligned bases was 16, i.e. $8.9 \%$. Across the set of the isolates, 21 position changes occurred, 12 of them in the last 80 sites. From the difference matrix (Table 4) and corresponding tree and bootstrap analysis (Fig. 1), except for isolate LARS 921 that was identical to $G$. cingulata (LARS 238), all the isolates from cashew and associated plants appeared to be very closely related (> $98.9 \%$ homology) to each other and to C. gloeosporioides obtained from C. melo (LARS 781), $M$. indica (LARS 501), A. virginica (LARS 074), S.scabra (LARS 167) and S. sp (LARS 189).

Table 4 - Difference matrix of Domain 2 region of LSU rDNA from different Colletotrichum/Glomerella isolates (LARS 905-940), from cashew and associated plants, and other representative of both genera. ${ }^{1}$

\begin{tabular}{|c|c|c|c|c|c|c|c|c|c|c|c|c|c|}
\hline Isolate - LARS & 058 & 141 & 202 & $\begin{array}{c}167 \\
\text { or } \\
189 \\
\end{array}$ & $909^{2}$ & 501 & $906^{3}$ & 781 & $905^{4}$ & $912^{5}$ & 009 & 238 & 921 \\
\hline 058 - C.acutatum & 0.000 & & & & & & & & & & & & \\
\hline 141 - C.capsici & 0.056 & 0.000 & & & & & & & & & & & \\
\hline 202 - C.destructivum & 0.022 & 0.033 & 0.000 & & & & & & & & & & \\
\hline 167 - C.gloeosporioides & 0.050 & 0.039 & 0.028 & 0.000 & & & & & & & & & \\
\hline 189 - C.gloeosporioides & 0.050 & 0.039 & 0.028 & 0.000 & & & & & & & & & \\
\hline $909-$ C.sp. ${ }^{2}$ & 0.050 & 0.039 & 0.028 & 0.000 & 0.000 & & & & & & & & \\
\hline $501-C$. gloeosporioides & 0.039 & 0.039 & 0.028 & 0.011 & 0.011 & 0.000 & & & & & & & \\
\hline $906-C$. sp. $^{3}$ & 0.039 & 0.033 & 0.033 & 0.011 & 0.011 & 0.000 & 0.000 & & & & & & \\
\hline 781 -C.gloeosporioides & 0.044 & 0.044 & 0.028 & 0.006 & 0.006 & 0.006 & 0.006 & 0.000 & & & & & \\
\hline 905-C.sp. ${ }^{4}$ & 0.044 & 0.044 & 0.028 & 0.006 & 0.006 & 0.006 & 0.006 & 0.000 & 0.000 & & & & \\
\hline 912 - C.sp. ${ }^{5}$ & 0.044 & 0.033 & 0.022 & 0.011 & 0.011 & 0.006 & 0.006 & 0.011 & 0.011 & 0.000 & & & \\
\hline 009 - C.lindemuthianum ${ }^{6}$ & 0.089 & 0.078 & 0.072 & 0.056 & 0.056 & 0.067 & 0.067 & 0.061 & 0.061 & 0.067 & 0.000 & & \\
\hline 238 - G. cingulata & 0.072 & 0.039 & 0.050 & 0.033 & 0.033 & 0.039 & 0.039 & 0.039 & 0.039 & 0.039 & 0.056 & 0.000 & \\
\hline 921 - C.sp. & 0.072 & 0.039 & 0.050 & 0.033 & 0.033 & 0.039 & 0.039 & 0.039 & 0.039 & 0.039 & 0.056 & 0.000 & 0.000 \\
\hline
\end{tabular}

${ }^{1}$ Differences are calculated as a proportion of the sites with differences (transition and transversion only, counted as one). ${ }^{2}$ also LARS 938 (G3); ${ }^{3}$ also LARS 074, 907, 910, 911, 914, 915, 916, 918, 919, 920, 925, 926, 928, 929, 930, 932, 933, 934, 935, 936, 937, 939 (G2); ${ }^{4}$ also LARS 908, 922, 923 (G1); ${ }^{5}$ also LARS 913, 917, 924, 927, 931, $940(\mathrm{G} 4) ;{ }^{6}$ also C. orbiculare (LARS 414), C. malvarum (LARS 076), C. trifolii (LARS 164). 


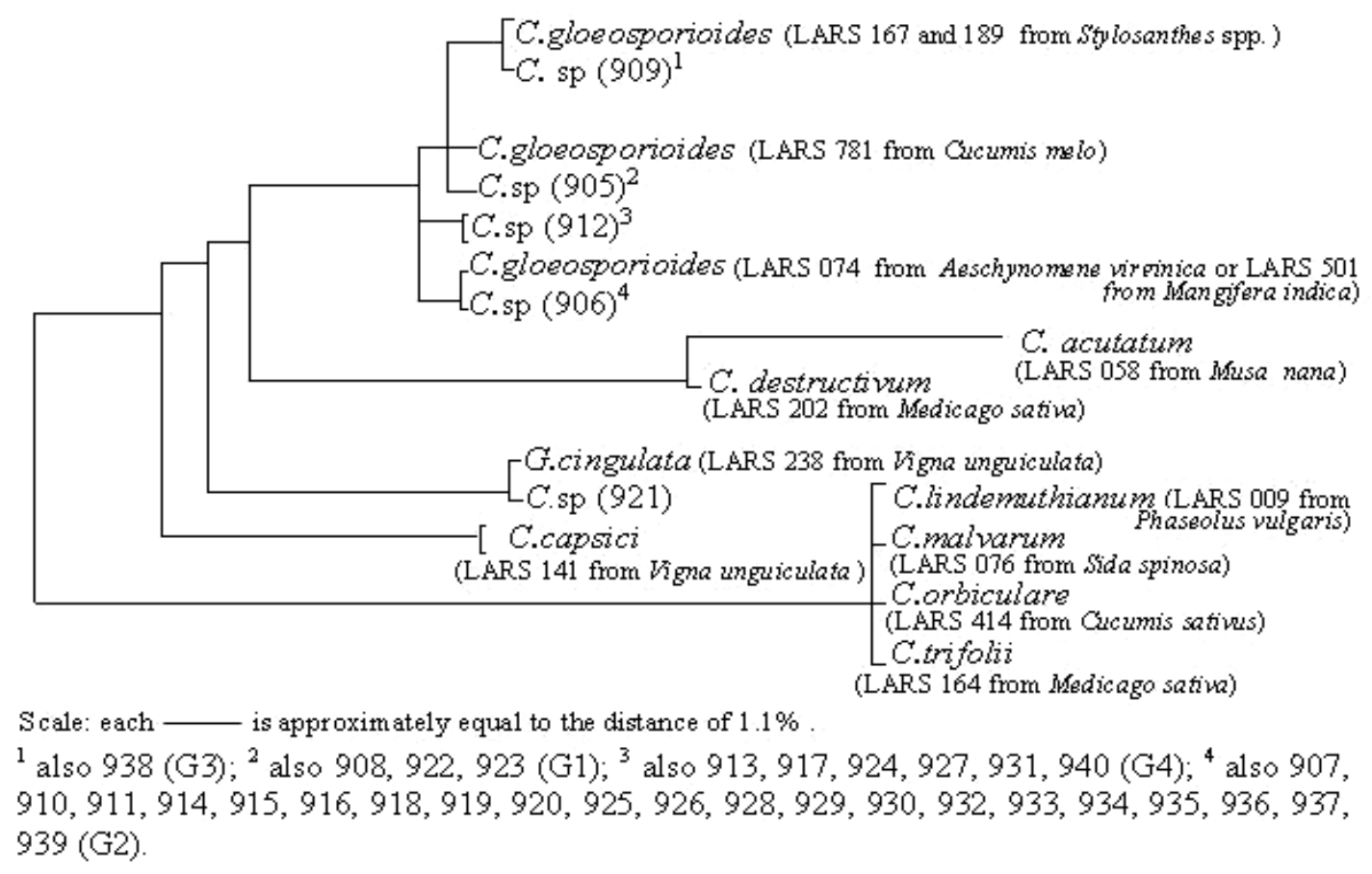

Figure 1 - Dendrogram illustrating the relationships between the Colletotrichum/Glomerella isolates LARS 905-940 from cashew and associated plants, and reference isolates LARS 009, 058, 074, 076, 141, 164, 167, 202, 238, 414, 501, 781 .

The maximum number of differences among the aligned bases of these isolates from the ones of the references were: C. lindemuthianum (LARS 009), C. trifolii (LARS 164), C. malvarum (LARS 076) and $C$. orbiculare (LARS 414) - 6.7\%; C. acutatum (LARS 058) -5.0\%; C. capsici (LARS 141) - 4.4\%; and C. destructivum (LARS 202) $3.9 \%$. Among the studied isolates LARS 905-940, four groups (G1-G4) of C. gloeosporioides were observed to occur. Isolates LARS 905, 908, 922 and 923 (G1) were identical to C. gloeosporioides from C. melo (LARS 781), and differed by only one nucleotide from $C$. gloeosporioides obtained from A. virginica (LARS 074), Stylosanthes spp. (LARS 167 and 189) and M. indica (LARS 501). Isolates LARS 906, 907, 910, 911, 914, 915, 916, 918, 919, 920, 925, 926, 928, 929, 930, 932, 933, 934, 935, 936, 937 and $939(\mathrm{G} 2)$ were identical to C. gloeosporioides obtained from A. virginica or $M$. indica but differed by two nucleotides from the isolates of Stylosanthes spp. Isolates LARS 909 and 938 (G3) were identical to the ones obtained from Stylosanthes spp., and isolates from G4 (LARS 912, 913, 917, 924, 927, 931, and 940) differed by two nucleotides from those in Stylosanthes spp., and by only one nucleotide from those on $A$. virginica, $M$. indica or $C$. melo. Different regions (D1, D2) of the LSU rDNA and intergenic sequences (ITS1, ITS2) have more variation in their rate of evolution than do the domains of the small subunit, being useful to distinguish groups in closely related taxa, like in the genus Colletotrichum (Bailey et al., 1996; Kohn, 1992; Moses et al., 1996; Moriwaki et al., 2002). Sherriff et al. (1994; 1995) observed that sequence data from the D2 region was as informative as the combined D1, D2 and ITS2 regions $(886 \mathrm{bp})$ in revealing the differences and relationships in Colletotrichum, since it has a sufficient proportion of sequence divergence to distinguish between the main species of this genus. Moses et al. (1996) identified C. gloeosporioides as the causal agent of stem tip dieback of cassava (Manihot esculenta), based on the relatedness between their D2-rDNA sequences and the ones of other Colletotrichum isolates. The authors found that cassava $C$. gloeosporioides isolates differed by only one nucleotide from those of A. virginica, $M$. indica and Stylosanthes spp., exactly as for some isolates in the present study.

Sreenivasaprasad et al. (1996) reported that, for a 
limited number of Colletotrichum species, the ITS1 region of rDNA showed a greater degree of intra and interspecific divergence $50.3 \%$ variable sites) than the ITS2 region (12.4\% variable sites). Considering the isolates of $C$. gloeosporioides and C. fragariae, which did not diverge in ITS2 sequence but diverged $(2.4 \%)$ in their ITS1 regions, Sreenivasaprasad et al. (1996) suggested that $C$. fragariae could be accommodated within the broad species concept of $C$. gloeosporioides. With regard to intraspecific variability in ITS1 of these 26 isolates of C. gloeosporioides, the sequences were identical in size (171 bp), but showed up to $3.6 \%$ nucleotide variability.

Abang et al. (2002), however, failed to distinguish between $C$. coccodes and $C$. circinans based on the restriction analysis of their ITS sequence, and Cano et al. (2004) demonstrated that sequencing of the domains D1-D2 of the LSU rDNA gene also supported the results provided by the amplification of ITS1 in distinguishing between the species of Colletotrichum of human clinical interest.

According to the results of this work, the sequence analysis of the Domain 2 region allowed to show the differences between the main species of Colletotrichum, especially when the morphological criteria were inconclusive. Even a small difference $(3.3 \%)$ distinguished the isolate LARS 921 from the others, described in four groups of $C$. gloeosporioides. The D2-rDNA nucleotide sequence of LARS 921 was identical to $G$. cingulata from $V$. unguiculata, and although it produced perithecia in different media, another 23 isolates did the same. Hence, the presence of perithecia and host origin could not be adopted as criterion to distinguish between the species.

Pathogenicity tests performed by Lopez (1999) showed that different cashew clones were infected by the isolates of $C$. gloeosporioides obtained from cashew and other susceptible plants, cultivated in close proximity in Brazil. The present work corroborated this evidence for anthracnose cross-infection in cashew, since it showed that polymorphism of the D2 sequences of the $28 \mathrm{~S}$ rDNAs of these isolates was not enough to clearly distinguish within the species - the four sub-groups of isolates had origins as distant as Rubus (LARS 905), Spondias (LARS 906), Carica (LARS 907), Dioscorea (LARS 908), Cucumis melo (G1 + LARS 781), Mangifera (G2 + LARS 501), and Stylosanthes spp. (G3 + LARS 167). This information must improve the effective measures of cashew-anthracnose control and the breeding programs. For a more detailed study of divergences among the isolates of $C$. gloeosporioides from cashew and its associated plants, a larger number of isolates and sequencing of their ITS1 rDNA region and DGGE of their $18 \mathrm{~S}$ rDNA should be included.

\section{RESUMO}

Trinta e seis isolados de fungos obtidos de lesões de antracnose em cajueiros e outras plantas consorciadas no Brasil, foram comparados quanto a seus aspectos culturais, morfológicos e seqüências parciais do rDNA 28S. Os isolados apresentaram elevado grau de variabilidade cultural, com taxa de crescimento médio, em todos os meios testados, entre 10,2 e $13,3 \mathrm{~mm} / \mathrm{dia}$. A maioria deles produziu peritécios (estéreis e férteis), e alguns produziram setas (estéreis e férteis) nos diferentes meios. Todos apresentaram acérvulos com predominância de conídios cilíndricos $(12,4-17,7 \mu \mathrm{m} \quad \mathrm{X} \quad 4,8-6,0 \mu \mathrm{m})$, de extremidades arredondadas, formando septos durante a germinação e produzindo apressórios ligeiramente lobados ou lisos. Comparando as sequiências do domínio D2 da larga subunidade (LSU) do rDNA dos isolados com aquelas já identificadas de espécies de Colletotrichum/ Glomerella, verificou-se que 35 deles correspondem a C. gloeosporioides (> 98,9\% de homologia), e um deles, o isolado 921, é idêntico a G. cingulata (LARS 238) de V. unguiculata.

\section{AKNOWLEDGEMENTS}

CAPES (Coordenação de Aperfeiçoamento de Pessoal de Nível Superior- Br); BBSRC (Biotechn. and Biological Sciences Research Council - UK).

\section{REFERENCES}

Abang, M.M.; Winter, S.; Green, K.R.; Hoffmann, P.; Mignouna, H.D.; Wolf, G.A. (2002), Molecular identification of C. gloeosporioides causing anthracnose of yam in Nigeria. Pl. Pathol., 51, 63-71.

Adaskaveg, J. E.; Hartin, R. J. (1997), Characterization of Colletotrichum acutatum isolates causing anthracnose of almond and peach in California. Phytopath., 87, 979-987. 
Agostini, J. P.; Timmer, L.W.; Mitchell, D. J. (1992), Morphological and pathological characteristics of strains of Colletotrichum gloeosporioides from citrus. Phytopath., 82, 1377-1382.

Alahakoon, P.W.; Brown, A. E. (1994), Host range of Colletotrichum gloeosporioides on tropical fruits in Sri Lanka. Internat. J. Pest Manag., 40, 23-26.

Andrade, E. M.; Uesugi, C. H.; Ueno, B.; Ferreira, M. A.S.V. (2007), Caracterização morfológica e cultural de Colletotrichum gloeosporioides patogênico ao mamoeiro. Fitop. Bras., 32, 21-31.

Bailey, J.A.; Nash, C.; Morgan, L.W.; O'Connell, R.J.; Te Beest, D.O. (1996), Molecular taxonomy of Colletotrichum species causing anthracnose on the Malvaceae. Phytopath., 86, 1076-1083.

Baxter, A. P.; Westhuizen, G. C. A.; Eicker, A. (1983), Morphology and taxonomy of South African isolates of Colletotrichum . South Af. J. Bot., 2, 260-289.

Brown, A. E.; Sreenivasaprasad, S.; Timmer, L.W. (1996). Molecular characterization of slow-growing orange and lime key anthracnose strains of Colletotrichum from citrus and C. acutatum. Phytopath., 86, 523-527.

Cannon, P.F.; Buddie, A.G. ; Bridge, P.D. (2008), The thypification of Colletotrichum gloeosporioides. Mycotaxon, 104, 189-204.

Cano, J.; Guarro, J.; Gene, J. (2004). Molecular and Morphological identification of Colletotrichum spp. of Clinical Interest. J.Clin. Microb., 42, 2450-2454.

Cox, M. L and Irwin, J.A.G. (1988), Conidium and appressoria variation in Australian isolates of the Colletotrichum gloeosporioides group and closely related species. Austr. System. Bot., 1, 139-149.

Fagbola, O.; Abang, M.M. (2004), Colletotrichum circinans and Colletotrichum coccodes can be distinguished by DGGE analysis of PCR-amplified 18S rDNA fragments. Af. J. Biotech., 3 , 195-198.

FAOSTAT (2008), Food and Agriculture Organization for United Nations - Statistical Database Homepage. http://faostat.fao.org/site/567/DesktopDefault.aspx?P ageID $=567$.

Forseille, L. (2007), Molecular and Pathological Differentiation of Colletotrichum truncatum from Scentless Chamomile and Legume Crops. Canada, Saskatchewan, Saskatoon: 122 p. Thesis (M.Sc.)Biology Department, Univ. of Saskatchewan.

Freeman, S.; Minz, D.; Jurkevitch, E.; Maymon, M.; Shabi, E. (2000), Molecular analyses of Colletotrichum species from almond and other fruits. Phytopath., 90, 608-614..

Freeman, S.; Minz, D.; Maymon, M.; Zveibil, A. (2001), Genetic diversity within Colletotrichum acutatum sensu Simmonds. Phytopath., 91, 586-592.

Freire, F. P.; Cardoso, J. E. (1995), Doenças do Cajueiro. In: Cajucultura: Modernas Técnicas de Produção. Ed. Araújo, J.P.P.; Da Silva, V.V., Empresa Brasileira de Pesquisa Agropecuária (EMBRAPA), Brazil, Fortaleza, pp. 249-267.
Gonçalves-Vidigal, M.C.; Thomazella, C.; Vidigal F ${ }^{o}$. P.; Kvitschal, M.V.; Elias, H.T. (2008). Characterization of Colletotrichum lindemuthianum Isolates Using Differential Cultivars of Common Bean in Santa Catarina State, Brazil. Braz. arch. biol. technol., 53, n.5, p. 883-885.

Graham, C.G.; Mayers, P.; Henry, J.R.A (1994), simplified method for the preparation of fungal genomic DNA for PCR and RAPD analysis. Biotechnol., 16, 48-50.

Guadet, J.; Julien, J.; Lafay, J. F.; Brygoo, Y. (1989), Phylogeny of some Fusarium species, as determined by large-subunit rRNA sequence comparison. Molec. Biol. Evol.,. 6, 227-242.

Gunnel, P. S.; Gubler, W. D. (1992), Taxonomy and morphology of Colletotrichum species pathogenic to strawberry. Mycol., 84, 157-165.

Irwin, H. R.; Cameron, D. F. (1978), Two diseases in Stylosanthes spp. caused by Colletotrichum gloeosporioides in Australia and pathogenic specialisation within one of the causal organisms. Austr. J. Agric. Res., 29, 305-317.

Jeffries, P.; Dodd, J. C.; Jeger, M. J.; Plumbley, R. A. (1990), The biology and control of Colletotrichum sp. on tropical fruit crops. Pl. Pathol., 39, 343-366.

Johnston P.R. (2000), The importance of phylogeny in understanding host relationships within Colletotrichum. In: Colletotrichum: host specificity, pathogenicity, and host-pathogen interactions, Prusky, D., Dickman, M.B., Freeman, S., eds. St. Paul, Minnesota: APS Press. pp 21-28

Johnston, P.R. and Jones, D.(1997), Relationships among Colletotrichum isolates from fruit-rots assessed using rDNA sequences. Mycol., 89, 420430.

Kohn, L. M. (1992), Developing new characters for fungal systematic: an experimental approach for determining the rank of resolution. Mycol., 84, 139-153.

Kumar, S.; Tamura, K.; Nei, M. (1993), MEGA: Molecular Evolutionary Genetic Analysis. Ver. 1.01. USA, Pennsylvania : The Pennsylvania St. Univ.

Kuramae-Izioka, E. E.; Lopes, C. R.; Souza, N. L.; Machado, M. A. (1997), Morphological and molecular characterization of Colletotrichum spp. from citrus orchards affected by postbloom fruit drop in Brazil. Europ. J. Pl. Pathol., 103, 323-329.

Lane, C. R.; Jeuland, H.; Hall, A.G.; Chesmore, E.D. (1998), Image analysis as an aid to discrimination between $C$. acutatum and $C$. gloeosporioides. In: 7th Internat. Congress of Plant Pathology, Edinburgh: Scotland. Abstracts, Vol. 3, Theme 4, Abs. 4.3.2.

Lenné, J. M. (1978), Studies on the biology and taxonomy of Colletotrichum species. Thesis (Ph.D.) Melbourne, Australia: Univ. of Melbourne.

Lima F ${ }^{\circ}$, R.M., Oliveira, S.M.A.;Menezes, M. (2003), Caracterização enzimática e patogenicidade cruzada de Colletotrichum spp. associados a doenças de póscolheita. Fitop. Bras., 28,620-625. 
Lopez, A. M. Q. (1999), The Interaction between anthracnose, Colletotrichum gloeosporioides Penz., and cashew, Anacardium occidentale (L.). BristolUK: 276p. Thesis (Ph.D.), LARS, Univ. of Bristol.

Mathur, R. S.; Barnett, H. L.; Lilly V. G. (1950), Sporulation of Colletotrichum lindemuthianum in culture. Phytopath., 40, 104-114.

Menezes, M. and Hanlin, R.J. (1996a), Morphological variability of Colletotrichum gloeosporioides from avocado trees from Northeastern Brazil. Rev. Microbiol., 27, 228-236.

Menezes, M. and Hanlin, R.J. (1996b), Appressoria of Brazilian isolates of Colletotrichum gloeosporioides (Penz.) Sacc. causal agent of anthracnose diseases. Braz. J. Microb., 27, 247-251.

Moriwaki, J.; Tsukiboshi, T.; Sato, T. (2002), Grouping of Colletotrichum species in Japan based on rDNA sequences. J. Gen. Pl. Pathol. 68, 307-320.

Moses, E.; Nash, C.; Strange, R.N.; Bailey, J.A. (1996), Colletotrichum gloeosporioides as the cause of stem tip dieback of cassava. Pl. Pathol., 45, 864-871.

Munaut, F.; Hamaide, N.; Maraite, H. (2001), Molecular and morphological characterization of Colletotrichum gloeosporioides from native Mexican Stylosanthes species. Pl. Pathol., 50, 383-396.

Muniz, M. F. S.; Lemos, E. E. P.; Várzea, V. M. P.; Rodrigues, J. R.; Bessa, A. (1997), Characterization of C. gloeosporioides (Penz.) Sacc. isolates and resistance of cashew (Anacardium occidentale L.) to the pathogen. In: International Cashew and Coconut Conference in Tanzania. Proceedings. Reading, UK: BioHybrids International Ltd. Publisher, pp. 249-253.

O'Connell, R. J.; Bailey, J. A.; Richmond, D. V. (1985). Cytology and physiology of infection of Phaseolus vulgaris by Colletotrichum lindemuthianum. Physiol. Pl. Pathol., 27, 75-98.

Sambrook, J.; Fritsch, E.F.; Maniatis, T. (1989). Molecular cloning: a laboratory manual, 2nd ed., New York: Cold Spring Harbor Laboratory Press, Vols.1-3, 1659 p.
Sera, G.H.; Sera, T.; Ito, D.S.; Azevedo, J.A.; Ribeiro F, C. ; da Mata, J.S. (2007). .Partial resistance to Fruit Necrosis Associated to Colletotrichum spp. among Arabic Coffee Genotypes. Brazilian Archives of Biology and Technology, vol. 50, n.3, p. 395-402.

Sherriff, C.; Whelan, M. J.; Arnold, G. M.; Lafay, J. F.; Brygoo, Y.; Bailey, J. A. (1994), rDNA sequence analysis reveals new species groupings in the genus Colletotrichum . Experim. Mycol., 18, 121-138.

Sherriff, C.; Whelan, M. J.; Arnold, G.M.; Lafay, J.F.; Brygoo, Y.; Bailey, J.A. (1995), rDNA sequence analysis confirms distinction between $C$. graminicola and C. sublineolum. Mycol. Res., 99, 475-478.

Sindicaju (2008), Homepage of the "Sindicato das Indústrias de Beneficiamento de Castanha de Caju e Amêndoas do Estado do Ceará - Exportação". http://www.sindicaju.org.br/site/exportacao.html.

Skipp, R. A.; Beever, R. E.; Sharrock, K. R, Rikkerink, E. H. A.; Templeton, M. D. (1995), Colletotrichum . In: Pathogenesis and host specificity in plant diseases, Kohmoto K, Singh U.S., Singh R.P., eds. Oxford, UK: Pergamon/Elsevier Sci. Ltd. Publisher, Vol. 2, pp. 119-142.

Smith, B.J.; Black, L.L.(1990), Morphological, cultural, and pathogenic variation among Colletotrichum species isolated from strawberry. Pl. Dis., 4, 69-76.

Sreenivasaprasad, S.; Mills, P. R.; Meehan, B. M.; Brown, A. E. (1996) Phylogeny and systematics of 18 Colletotrichum species based on ribosomal DNA spacer sequences. Genome, 39, 499-512.

Vinnere, O.; Fatehi, J.; Wright, S.A.I.; Gerhardson, B. (2002), The causal agent of anthracnose of Rhododendron in Sweden and Latvia. Mycol. Res., 106, 60-69. 